As with other sections of the Restatement, 10 Comments and 13 Reporters' Notes elaborate on these terse phrases, describing the various exceptions and limitations to the doctrine that have grown up, some confirmed by the Supreme Court, others still in doubt. ${ }^{15}$ It is in these intersticesexceptions, limitations and interpretations of the limitations-that the act of state doctrine in the United States seems to us likely to develop. The Restatement does not provide instant answers to the many issues that have arisen, but it provides a convenient-and we believe correct-point of departure for the courts, for advisers and for advocates.

We have attempted to report on the act of state doctrine, as on many other doctrines and puzzles in our field, as scholars and not as advocates. We have come neither to praise Sabbatino nor to bury it. There having been no burial, there can hardly have been a resurrection-with or without the Restatement.

LOUIS HENKIN

ANDREAS F. LOWENFELD*

TO THE EdITOR IN CHIEF:

March 20, 1985

In a review of the Soviet Year-Book of International Law 1982, published in your October 1984 issue (at p. 1018), Dr. E. T. Usenko is presented as a scholar "well known for his participation in the International Law Commission's work" (p. 1019). Knowing Professor Usenko's erudition and diplomatic skills, I have little doubt that, given a chance, he would ably represent the Soviet legal doctrine in that prestigious body. The fact remains, however, that since 1967 another recognized international lawyer-Professor Nikolai A. Ushakov-has been the Soviet member of the Commission. He is the fifth Soviet scholar to serve in this capacity. Vladimir M. Koretsky (1949-1952), Feodor I. Kozhevnikov (1952-1953), Sergei B. Krylov (1954-1956) and Grigory I. Tunkin (1957-1966) were his predecessors.

Maria Frankowska Southern Illinois University School of Law

\title{
The Francis Deák Prize
}

The Board of Editors of the American Journal of International Law announces with pleasure the selection of Michael J. Glennon as recipient of the Francis Deák Prize for 1985. The prize was awarded to Professor Glennon for his article, The War Powers Resolution Ten Years Later: More

\footnotetext{
${ }^{15}$ See, e.g., the exception for commercial transactions set forth in part III of Alfred Dunhill of London, Inc. v. Republic of Cuba, 425 U.S. 682, 695-706 (1976), concurred in by only four of the five Justices making up the majority in that case, but not by Justice Stevens.

* Of the Board of Editors. Professors Henkin and Lowenfeld are, respectively, Chief Reporter and one of the associate reporters of the Restatement of the Foreign Relations Law of the United States (Revised).
} 